\title{
Indexação do Lettuce mosaic virus em sementes e plântulas de genótipos de alface ${ }^{1}$
}

\author{
Lillian Silveira Pereira ${ }^{2}$, Alexandre Levi Rodrigues Chaves ${ }^{2}$, \\ Joaquim Adelino Azevedo Filho ${ }^{3}$, Addolorata Colariccio ${ }^{2 *}$
}

\begin{abstract}
RESUMO - O Lettuce mosaic virus espécie mais importante na cultura de alface (Lactuca sativa L.) no Brasil, causando sintomas de mosaico, clareamento das nervuras, necrose, distorção foliar e redução do crescimento da planta, pode ser transmitido por sementes com uma taxa de $1 \%$ a $16 \%$, dependendo da interação dos genótipos de alface com os isolados LMV-Most ou LMV-Common. Neste trabalho, avaliou-se a detecção do LMV por PTA-ELISA, em sementes e plântulas de oito genótipos de alface: 'Vanessa Roxa', 'Baba de Verão', 'Verdinha', 'Maravilha das 4 Estações', 'Evely', 'Marcela', 687 ('Sapore' x 'Vera'), 784 ('Sapore'x 'Vera'), utilizando anti-soro policlonal específico. $\mathrm{O}$ vírus não foi detectado em sementes do genótipo 'Verdinha' e, em plântulas dos genótipos 687, 'Marcela' e 'Evely', após a germinação em papel e 687, 784 e 'Marcela' com gene $m o 1^{1}$, após a germinação em substrato. A avaliação individual do número de sementes infectadas foi de 100\% para 'Vanessa Roxa' e 'Baba de Verão', 87,7\% para 'Verdinha', 46,6\% para 'Maravilha das 4 Estações' e 16,6\% para 'Evely'. Nos genótipos com gene de resistência o percentual foi de 15,6\%, 26,6\%, 90\% em 'Marcela', 687 e 784, respectivamente. A detecção do LMV por PTA-ELISA foi eficiente tanto em sementes quanto em plântulas.
\end{abstract}

Termos para indexação: alface, detecção, sementes, sorologia e genótipos.

\section{Lettuce mosaic virus indexation in seeds and seedlings of lettuce genotypes}

\begin{abstract}
Lettuce mosaic virus is the major virus in lettuce (Lactuca sativa L.) in Brazil, causing symptoms of mosaic, vein clearing, necrosis, leaf distortion and growth reduction. The LMV is transmitted by seeds at a rate of $1 \%$ to $16 \%$, mostly due to interaction between the isolates LMV-Most and LMV-Common and the lettuce cultivar. In this study, LMV detection by PTA-ELISA in seeds and seedlings of eight lettuce genotypes, 'Vanessa Roxa', 'Baba de Verão', 'Verdinha', 'Maravilha das 4 Estações', 'Evely', 'Marcela', 687 ('Vera' X 'Sapore'), 784 ('Vera' $\mathrm{X}$ 'Sapore'), was evaluated, using specific polyclonal antisera. The virus was not detected in seeds of 'Verdinha' genotype and seedlings of 687, 'Marcela' and 'Evely' after germination in a paper towel or in 687, 784 and 'Marcela' with the $\mathrm{mol}^{1}$ resistance gene, after germination in a substrate. The individual evaluation of the number of infected seeds made by PTA-ELISA was $100 \%$ for 'Vanessa Roxa' and 'Baba de Verão', $87.7 \%$ for 'Verdinha', $46.6 \%$ for 'Maravilha das 4 Estações' and $16.6 \%$ for 'Evely'. In the genotypes with the resistance gene the percentage was $15.6 \%, 26.6 \%, 90 \%$ in 'Marcela', 687 and 784, respectively. Virus detection in seeds and seedlings by PTA-ELISA was very efficient for both seeds and seedlings.
\end{abstract}

Index terms: lettuce, detection, seed, serology, genotypes.

${ }^{1}$ Submetido em 13/05/2011. Aceito para publicação em 06/05/2012.

${ }^{2}$ Instituto Biológico, Laboratório de Fitovirologia e Fisiopatologia, 04114-002-São Paulo, SP, Brasil.
${ }^{3}$ Pólo Regional Leste Paulista Monte Alegre do Sul, 13910-000-Monte Alegre do Sul, SP, Brasil.

*Autor para correspondência <colariccio@biologico.sp.gov.br> 


\section{Introdução}

A transmissão de vírus por sementes ocorre em aproximadamente, $18 \%$ das espécies de vírus descritas, por uma ou mais das suas hospedeiras naturais e, um terço dos vírus pode ser transmitido por pelo menos uma de suas hospedeiras (Hull, 2002). Para a maioria das interações vírus hospedeiro, a semente pode oferecer uma efetiva barreira contra a passagem dos vírus, mesmo quando estes são altamente infectivos (Daniels, 1999). Apesar dessa barreira, existem vírus que passam de uma geração a outra pelas sementes (Bennett, 1969; Shepherd, 1972), existindo aproximadamente 100 espécies de vírus transmitidos por sementes, dos quais 18 pertencem ao gênero Nepovirus; 17 ao gênero Potyvirus; 13 ao gênero Alphacryptovirus; 9 ao gênero Ilarvirus e outras espécies em 21 dos demais gêneros de vírus (Batista e Marinho, 2002; Zerbini, 2005).

A transmissão de vírus por sementes pode ser influenciada pela espécie ou genótipo do hospedeiro, pela espécie ou patotipo do vírus, pelas condições ambientais, pela idade da planta mãe e mais frequentemente, pela infecção dos gametas antes da fertilização, embora para alguns vírus a infecção ocorra após a fertilização (Maule e Wang, 1996).

Dentre os vírus transmitidos por sementes, o Lettuce mosaic virus (LMV) é o mais disseminado no Brasil (Zerbini, 2005) e em todo o mundo, podendo infectar diversas variedades de alface e causar sérios prejuízos à cultura (Dinant e Lot, 1992; Zerbini, 2005).

OLMV pertenceà família Potyviridae, gênero Potyvirus, possui partículas alongadas, medindo aproximadamente $750 \mathrm{~nm}$ de comprimento e $13 \mathrm{~nm}$ de diâmetro (Fauquet et al., 2005) com genoma composto por uma molécula de RNA fita simples, sentido positivo (Dinant e Lot, 1992). O LMV é transmitido por sementes de alface, nas quais infecta os tecidos embrionários (Tomlinson, 1970).

A epidemiologia do LMV está associada à transmissão por sementes, cuja taxa varia de acordo com o patotipo e a cultivar utilizada (Dinant e Lot, 1992; Jadão et al., 2002), à rápida disseminação pelos afídeos vetores, sendo as principais espécies descritas no Brasil, Myzus persicae, Aphis gossypii, A. fabae, Macrosiphum solanifolli e Uroleucon sonchi (Costa,1998), das quais destacam-se como mais eficientes A. gossypii, $A$. fabae e também à ocorrência de espécies da vegetação espontânea (Chaves et al., 2007).

No Brasil, em genótipos de alface sem genes de resistência foi constatada uma alta taxa de transmissão pelas sementes $(16,5 \%)$, enquanto em genótipos com os genes de resistência $m o 1^{1}$ e $m o l^{2}$ foram constatadas baixas taxas de transmissão (1,9\%) (Jadão et al., 2002). Mas, mesmo com baixas taxas de transmissão de 0,001 aproximadamente, a porcentagem de plantas infectadas pode ser alta, devido a posterior disseminação do vírus, por afídeos vetores causando severas perdas na produção (Hull, 2002). No Brasil, também ocorreram perdas totais em campos de alface com populações ativas de afídeos, mesmo quando a porcentagem de transmissão pelas sementes foi baixa, aproximadamente $0,5 \%$ (Pavan et al., 2005).

A transmissão de vírus pelas sementes não é uma regra, mas esta via pode ser uma fonte primária de infecção na cultura e pode representar um meio eficiente de sua introdução em regiões geográficas nas quais, ainda não ocorre, sendo responsável pela disseminação dos vírus a longas distâncias, devido ao intercâmbio nacional e internacional de sementes (Dinant e Lot, 1992; Chung et al., 2007).

A identificação dos patotipos, do LMV em sementes de alface é de fundamental importância, uma vez que, a porcentagem de transmissão pelas sementes está associada aos diferentes patotipos do LMV e ao comportamento das variedades resistentes ou tolerantes, podendo esta associação resultar em perda total da produção, sendo, um fator importante no controle do vírus, concomitantemente a produção de sementes certificadas (Krause-Sakate et al., 2001). O LMV pode ser transmitido pelas sementes do LMV-Common e LMV-Most, sendo que a taxa de transmissão pelas sementes do LMV-Most é de 1,9\% quando infecta genótipos com gene de resistência e de $16,6 \%$ quando infecta genótipos sem gene de resistência (Krause-Sakate et al., 2002).

Apesar dos fatores que levam à transmissão de vírus de planta por sementes não serem bem conhecidos, existem algumas teorias para explicar esse fenômeno. Hunter e Bowyer (1994), por imuno-marcação em embriões imaturos de alface constataram que partículas do LMV se encontravam em todos os tecidos do óvulo, exceto no saco embrionário. Porém, não foi possível determinar se as partículas do LMV presentes nos tecidos não-embrionários necessariamente tornavam as sementes infectadas (Hunter e Bowyer, 1994).

A detecção de vírus em sementes pode ser dificultada pela baixa concentração de partículas nas sementes, por isso os programas de indexação adotam o teste sorológico de ELISA para detectar a presença do vírus, devido a sua alta sensibilidade e possibilidade de avaliar um grande número de amostras (Hull, 2002). Entretanto, a eficiência do ELISA depende de diferentes fatores, dentre eles o tipo 
de placa, o antissoro, a preparação e o tempo de incubação da amostra, (Falk e Purciful, 1983).

Assim, tanto a determinação do número de sementes por amostra, quanto às técnicas utilizadas para avaliar a presença de vírus em sementes e plântulas torna-se extremamente importante, considerando que a taxa de transmissão varia de acordo com a combinação do cultivar e da espécie ou estirpe de vírus que infecta a cultura (Batista e Marinho, 2002).

Dentre as sementes importadas pelo Brasil estão as de alface, cuja sanidade no cultivo depende da qualidade fitossanitária, uma vez que o LMV é o mais disseminado nesta cultura, causando os maiores danos no campo (Batista e Marinho, 2002).

Este trabalho foi realizado com o objetivo de avaliar a presença do LMV em sementes e plântulas, em diferentes estádios de desenvolvimento, de variedades comerciais e linhagens promissoras de alface, bem como, propor um tamanho de amostra de sementes que possibilite a detecção segura do vírus.

\section{Material e Métodos}

Os experimentos foram realizados no Laboratório de Fitovirologia e Fisiopatologia (LFF) do Centro de Pesquisa e Desenvolvimento de Sanidade Vegetal (CPDSV), do Instituto Biológico, São Paulo, SP.

Foram avaliadas sementes de alface dos genótipos 'Baba de Verão', 'Maravilha das 4 Estações', 'Vanessa Roxa' e 'Verdinha', pertencentes ao Banco Ativo Germoplasma - Instituto Agronômico de Campinas (BAGIAC), provenientes de campo aberto do município de Jarinu, e sementes de alface das variedades 'Evely', 'Marcela', 687 ('Vera' X 'Sapore'), 784 ('Vera' X 'Sapore') do BAGEstação Experimental Hortec (BAG-EEH) provenientes do município de Bragança Paulista. Todas as sementes estavam acondicionadas em sacos de papel mantidos à $5^{\circ} \mathrm{C}$.

As amostras de cada genótipo avaliado foram constituídas de 3000 sementes, separadas em três lotes de 1000 sementes. Cada lote foi subdividido em 10 subamostras com 100 sementes por subamostra. A presença do LMV foi avaliada em cada um dos três lotes, constituído de 10 subamostras, em um dos lotes, diretamente nas sementes; em outro em plântulas após a germinação em papel filtro (gerbox) em substrato de papel filtro, e no último, em plântulas após a germinação em substrato comercial. Todas as subamostras foram avaliadas por PTA-ELISA com antissoro policlonal para o LMV.
A germinação das sementes das dez subamostras, em caixas de germinação foi realizada acondicionando cada subamostra de 100 sementes, em um dos quadrantes da caixa forrado com papel filtro (Germitest) umedecido com água esterilizada, totalizando 400 sementes em cada caixa, subdividida em quatro quadrantes sendo utilizadas 2,5 caixas para cada amostra. As caixas foram acondicionadas em câmara climatizada (BOD) em condições controladas de luz (20 watts) de $12 \mathrm{~h}$ de fotoperíodo positivo e temperatura de $25{ }^{\circ} \mathrm{C}$. As plântulas foram avaliadas no estádio de folhas cotiledonares, 15 dias após a semeadura.

A germinação das sementes em substrato das dez subamostras, em caixas plásticas de $30 \mathrm{~cm}$ de largura $\mathrm{X}$ $50 \mathrm{~cm}$ de comprimento contendo $100 \mathrm{~g}$ de substrato, foi realizada acondicionando cada subamostra de 100 sementes em duas caixas, cada uma subdividida em cinco compartimentos, totalizando 500 sementes em cada caixa. As caixas foram mantidas em casa de vegetação, até a germinação das sementes. As plântulas foram avaliadas no estádio de duas folhas verdadeiras desenvolvidas, cerca de 25 dias, após a semeadura.

A detecção sorológica do LMV por PTA-ELISA foi realizada para as 10 subamostras de sementes, de $L$. sativa das variedades empregadas neste trabalho. Cada subamostra foi constituída de 100 sementes. O extrato bruto das sementes e das plântulas em papel filtro e substrato foi obtido pela redução a pó das sementes ou das plântulas com nitrogênio líquido acrescentando-se a seguir o tampão Carbonato de Sódio 0,05 M, pH 9,6 na proporção de $1 / 10(\mathrm{~g} / \mathrm{mL})$. O PTA-ELISA foi realizado de acordo com (Clark e Adams 1977). Foram consideradas positivas as subamostras em que, a média da leitura da triplicata de cada um foi 3,0 vezes maior do que a média da leitura da triplicata do controle negativo. Como controles positivo e negativo foram empregados, respectivamente, extrato bruto de alface infectada pelo LMV e extrato bruto de alface sadia, obtidos pelo mesmo procedimento empregado para as subamostras avaliadas.

Para a avaliação da porcentagem de sementes L. sativa infectadas pelo LMV, foram empregadas 90 sementes de cada um dos genótipos avaliados. Cada semente foi macerada, individualmente, em tampão Carbonato de sódio $0,05 \mathrm{M}, \mathrm{pH} 9,6$ na proporção de $1 / 10(\mathrm{~g} / \mathrm{mL})$ e o extrato foi colocado em um único poço da placa de Elisa. $\mathrm{O}$ procedimento para o PTA-ELISA foi o mesmo empregado nos testes anteriores. A porcentagem de sementes infectadas de cada genótipo foi estimada pelo número de sementes positivas avaliadas na amostra total. 


\section{Resultados e Discussão}

De acordo com as Regras para Análise de Sementes do Ministério da Agricultura, as sementes dos genótipos de alface avaliadas apresentaram 100\% de germinação quando submetidas ao teste de germinação em substrato papel de filtro (Brasil, 2009). Nas plântulas obtidas em papel filtro, no período avaliado, houve somente o desenvolvimento das folhas cotiledonares. Porém, em substrato comercial, as plântulas desenvolveram as primeiras folhas verdadeiras, nas quais não foram visualizados sintomas de mosaico. A diferença do vigor das plântulas pode ser atribuída à falta de nutrientes para o desenvolvimento da primeira folha verdadeira em papel filtro, uma vez que não foi utilizada solução nutritiva e a germinação ocorreu com as reservas dos cotilédones das sementes (Zerbini, 2005). Estes resultados reforçam a necessidade da realização de testes fitossanitários complementares à inspeção visual de sintomas em mudas de alface provenientes de sementes, pois de acordo com Rohloff e Marrou (1981), plântulas desta espécie quando infectadas pelo LMV devem apresentar sintomas de mosaico a partir da terceira folha desenvolvida.

O resultado do PTA-ELISA para a presença do LMV nas 10 subamostras de sementes de $L$. sativa dos genótipos do BAG-IAC foi positivo para os genótipos 'Vanessa Roxa', 'Baba de Verão' e Maravilha das 4 Estações' e negativo para 'Verdinha'(Tabela 1). Os valores médios de absorbância para o controle positivo e negativo foram de 0,918 e 0,032 , respectivamente. Os valores da média de absorbância das 10 subamostras foram de $0,169,0,178$ e 0,609 , respectivamente, para 'Vanessa Roxa', 'Baba de Verão' e Maravilha das 4 Estações' e de 0,082 para 'Verdinha' (Tabela 1).

Tabela 1. Detecção do Lettuce mosaic virus (LMV) por PTA-ELISA em sementes e plântulas de Lactuca sativa após a germinação em papel filtro e substrato comercial dos genótipos do Banco Ativo de Germoplasma.

\begin{tabular}{|c|c|c|c|c|c|c|c|c|c|c|c|c|}
\hline \multirow[t]{2}{*}{$\begin{array}{l}\text { Subamostra } \\
(\mathrm{sem})^{1}\end{array}$} & \multicolumn{3}{|c|}{ 'Vanessa Roxa' } & \multicolumn{3}{|c|}{ 'Baba de Verão' } & \multicolumn{3}{|c|}{ 'Verdinha' } & \multicolumn{3}{|c|}{$\begin{array}{l}\text { 'Maravilha } \\
4 \text { estações' }\end{array}$} \\
\hline & $\mathrm{Sem}^{2}$ & $\mathrm{Ger}^{3}$ & Subt $^{4}$ & $\mathrm{Sem}^{2}$ & $\mathrm{Ger}^{3}$ & Subt $^{4}$ & $\mathrm{Sem}^{2}$ & $\mathrm{Ger}^{3}$ & Subt $^{4}$ & $\mathrm{Sem}^{2}$ & $\mathrm{Ger}^{3}$ & Subt $^{4}$ \\
\hline A (100) & 0,114 & 0,164 & 0,008 & 0,132 & 0,166 & 0,013 & 0,103 & 0,128 & 0,015 & 0,664 & 0,071 & 0,035 \\
\hline B (100) & 0,191 & 0,216 & 0,015 & 0,151 & 0,163 & 0,018 & 0,084 & 0,163 & 0,009 & 0,540 & 0,108 & 0,035 \\
\hline$C(100)$ & 0,169 & 0,227 & 0,022 & 0,119 & 0,160 & 0,018 & 0,078 & 0,297 & 0,028 & 0,534 & 0,121 & 0,032 \\
\hline $\mathrm{D}(100)$ & 0,140 & 0,286 & 0,023 & 0,169 & 0,142 & 0,013 & 0,092 & 0,257 & 0,012 & 0,612 & 0,267 & 0,082 \\
\hline E (100) & 0,157 & 0,137 & 0,016 & 0,208 & 0,137 & 0,019 & 0,072 & 0,331 & 0,011 & 0,618 & 0,167 & 0,032 \\
\hline$F(100)$ & 0,153 & 0,127 & 0,018 & 0,191 & 0,187 & 0,018 & 0,074 & 0,091 & 0,015 & 0,637 & 0,135 & 0,024 \\
\hline G (100) & 0,146 & 0,137 & 0,020 & 0,204 & 0,173 & 0,005 & 0,082 & 0,170 & 0,017 & 0,646 & 0,128 & 0,037 \\
\hline H (100) & 0,170 & 0,153 & 0,023 & 0,205 & 0,229 & 0,016 & 0,087 & 0,221 & 0,016 & 0,639 & 0,133 & 0,052 \\
\hline $\mathrm{I}(100)$ & 0,152 & 0,175 & 0,053 & 0,216 & 0,167 & 0,027 & 0,073 & 0,103 & 0,030 & 0,530 & 0,107 & 0,005 \\
\hline $\mathrm{J}(100)$ & 0,193 & 0,141 & 0,024 & 0,190 & 0,111 & 0,008 & 0,075 & 0,129 & 0,005 & 0,672 & 0,163 & 0,010 \\
\hline$\sum_{\text {subamostra })}$ (medias & 0,169 & 0,176 & 0,022 & 0.178 & 0,180 & 0,015 & 0,082 & 0,189 & 0,015 & 0,609 & 0,147 & 0,034 \\
\hline $\mathrm{C}+$ & \multicolumn{12}{|c|}{0,918} \\
\hline C- & \multicolumn{12}{|c|}{0,032} \\
\hline $\begin{array}{c}\text { Média } \\
\text { amostras/C- }\end{array}$ & 5,30 & 5,61 & 0,69 & 5,57 & 5,62 & 0,48 & 2,56 & 5,90 & 0,46 & 19,03 & 4,59 & 1,06 \\
\hline
\end{tabular}

${ }^{1}$ Subamostra: 1000 sementes de cada variedade sub amostradas em lotes de 100 sementes.

${ }^{2}$ Sem: Média do valor da absorbância do LMV na amostra de sementes de L. sativa.

${ }^{3}$ Ger: Média do valor da absorbância do LMV em plântulas de L. sativa germinadas em papel filtro.

${ }^{4}$ Subt: Média do valor da absorbância do LMV em plântulas de L. sativa germinadas em substrato comercial.

$\mathrm{C}+$ : Média do controle positivo.

C -: Média do controle negativo .

O resultado do PTA-ELISA para a presença do LMV nas 10 subamostras de sementes de L. sativa dos genótipos 'Marcela', 687 ('Vera' X 'Sapore'), 784 ('Vera' $\mathrm{X}$ 'Sapore') e 'Evely' do BAG-EEH, foi positivo para 
todos os genótipos avaliados (Tabela 2). Os valores médios de absorbância foram de 1,030 e 0,025 , para o controle positivo e negativo, respectivamente. Os valores da média de absorbância das 10 subamostras de 'Marcela', 687, 784 e 'Evely' foi de 0,440, 0,373, 0,468 e 0,138, respectivamente (Tabela 2).

Tabela 2. Detecção do Lettuce mosaic virus (LMV) por PTA-ELISA em sementes e plântulas de Lactuca sativa após a germinação em papel filtro e substrato comercial dos genótipos do Banco Ativo de Germoplasma.

\begin{tabular}{|c|c|c|c|c|c|c|c|c|c|c|c|c|}
\hline \multirow[t]{2}{*}{$\begin{array}{l}\text { Subamostra } \\
(\mathrm{sem})^{1}\end{array}$} & \multicolumn{3}{|c|}{$687^{, 5}$} & \multicolumn{3}{|c|}{$7844^{, 5}$} & \multicolumn{3}{|c|}{ 'Marcela' } & \multicolumn{3}{|c|}{ ‘Evely’ } \\
\hline & $\mathrm{Sem}^{2}$ & $\mathrm{Ger}^{3}$ & Subt $^{4}$ & $\mathrm{Sem}^{2}$ & $\mathrm{Ger}^{3}$ & Subt $^{4}$ & $\mathrm{Sem}^{2}$ & $\mathrm{Ger}^{3}$ & Subt $^{4}$ & $\mathrm{Sem}^{2}$ & $\mathrm{Ger}^{3}$ & Subt $^{4}$ \\
\hline $\mathrm{A}(100)$ & 0,449 & 0,064 & 0,080 & 0,399 & 0,082 & 0,064 & 0,441 & 0,073 & 0,089 & 0,131 & 0,078 & 0,076 \\
\hline $\mathrm{B}(100)$ & 0,395 & 0,062 & 0,077 & 0,486 & 0,087 & 0,088 & 0,440 & 0,053 & 0,082 & 0,152 & 0,068 & 0,059 \\
\hline$C(100)$ & 0,419 & 0,060 & 0,077 & 0,459 & 0,093 & 0,071 & 0,471 & 0,076 & 0,126 & 0,156 & 0,065 & 0,065 \\
\hline $\mathrm{D}(100)$ & 0,305 & 0,047 & 0,097 & 0,431 & 0,090 & 0,038 & 0,499 & 0,061 & 0,084 & 0,139 & 0,076 & 0,072 \\
\hline $\mathrm{E}(100)$ & 0,377 & 0,071 & 0,093 & 0,370 & 0,099 & 0,082 & 0,456 & 0,072 & 0,084 & 0,139 & 0,069 & 0,057 \\
\hline $\mathrm{F}(100)$ & 0,348 & 0,067 & 0,067 & 0,411 & 0,073 & 0,088 & 0,451 & 0,110 & 0,094 & 0,137 & 0,076 & 0,068 \\
\hline $\mathrm{G}(100)$ & 0,383 & 0,052 & 0,084 & 0,377 & 0,089 & 0,084 & 0,400 & 0,051 & 0,110 & 0,156 & 0,069 & 0,064 \\
\hline $\mathrm{H}(100)$ & 0,327 & 0,095 & 0,099 & 0,405 & 0,079 & 0,069 & 0,368 & 0,061 & 0,099 & 0,119 & 0,082 & 0,075 \\
\hline $\mathrm{I}(100)$ & 0,308 & 0,075 & 0,103 & 0,735 & 0,086 & 0,080 & 0,520 & 0,145 & 0,086 & 0,121 & 0,078 & 0,071 \\
\hline $\mathrm{J}(100)$ & 0,420 & 0,074 & 0,083 & 0,567 & 0,084 & 0,097 & 0,362 & 0,056 & 0,103 & 0,139 & 0,072 & 0,064 \\
\hline$\sum_{\text {subamostra })}$ (média & 0,373 & 0,066 & 0,085 & 0,464 & 0,086 & 0,163 & 0,440 & 0,073 & 0,095 & 0,138 & 0,073 & 0,067 \\
\hline $\mathrm{C}+$ & \multicolumn{12}{|c|}{1,03} \\
\hline C- & \multicolumn{12}{|c|}{0,025} \\
\hline $\begin{array}{c}\text { Média } \\
\text { amostras/C- }\end{array}$ & 14,92 & 2,66 & 3,41 & 18,56 & 3,44 & 6,53 & 17,63 & 2,92 & 3,82 & 5,55 & 2,93 & 2,68 \\
\hline
\end{tabular}

${ }^{1}$ Subamostra: 1000 sementes de cada variedade sub amostradas em lotes de 100 sementes.

${ }^{2}$ Sem: Média do valor da absorbância do LMV na amostra de sementes de L. sativa.

${ }^{3}$ Ger: Média do valor da absorbância do LMV em plântulas de L. sativa germinadas em papel filtro.

${ }^{4}$ Subt: Média do valor da absorbância do LMV em plântulas de L. sativa germinadas em substrato comercial.

${ }^{5}$ Genótipos de L. sativa com gene de resistência mol $^{1}$.

C+: Média do controle positivo.

C -: Média do controle negativo.

Os valores de absorbância da detecção do LMV em sementes foram altos nos genótipos 'Maravilha das 4 Estações' que não possui genes de resistência e nos genótipos 'Marcela', 687 e 784 que possuem o gene de resistência $m o 1^{1}$ que confere resistência ao patotipo II ou subgrupo LMV-Commom. Nos genótipos que possuem o gene $m o 1^{1}$ não ocorre a presença do LMV em sementes (Jadão et al., 2002), fato que não foi verificado para os genótipos 'Marcela', 687 e 784 (Tabela 2). Entretanto, os valores de absorbância foram baixos nos genótipos 'Evely', 'Vanessa Roxa', 'Baba de Verão' e nulos para 'Verdinha', que não possuem gene de resistência (Tabelas 1, 2). Este resultado evidencia que a presença do LMV nas sementes pode ser influenciada pelo genótipo do hospedeiro (Dinant e
Lot, 1992; Maule e Wang, 1996). Porém, além do genótipo outros fatores, como o subgrupo do LMV, a idade das plantas e fatores ambientais, podem influenciar a presença do LMV nas sementes, conforme relatado por (Dinant e Lot, 1992; Maule e Wang 1996). No genótipo 'Maravilha das 4 Estações' foram obtidos os valores de absorbância mais altos de detecção do LMV em sementes (Tabela 1).

Pelos resultados obtidos verificou-se que a ocorrência do LMV nas sementes está diretamente associada à combinação entre a cultivar e o isolado do vírus. Em estudos realizados por Krause-Sakate et al. (2002) com base na análise filogenética de 73 isolados de LMV com diferentes propriedades biológicas, a interação entre as cultivares de alface e os isolados do LMV ocorreu independentemente da presença dos alelos de 
resistência recessivos, com relação à capacidade de infectar sementes. Fato observado neste trabalho, uma vez que nas variedades com o gene de resistência foram obtidos valores altos de absorbância nas sementes infectadas, sendo que o esperado em genótipos com o gene de resistência $\mathrm{mol}^{1}$ seriam valores nulos de absorbância em sementes infectadas, de acordo com os resultados obtidos por (Jadão et al., 2002).

A detecção do LMV por PTA-ELISA, nas 10 subamostras de plântulas avaliadas, obtidas em papel filtro, foi positiva para todos os genótipos, com exceção dos 687, 'Marcela' e 'Evely'. A deteç̧ão do LMV nas 10 subamostras de plântulas germinadas em substrato comercial foi positiva, somente para os genótipos com o gene de resistência (Tabela 1). Neste caso houve a transmissão do LMV das sementes para as plântulas.

O resultado da detecção do LMV por PTA-ELISA, nas 10 subamostras de plântulas dos genótipos 'Marcela', 687, 784 e 'Evely', obtidas em papel filtro foi positivo, para 784 e negativo para os demais genótipos, enquanto a detecção do LMV nas 10 subamostras de plântulas germinadas em substrato comercial foi negativa, somente para 'Evely' e positivo para os demais genótipos (Tabela 2).

$\mathrm{O}$ resultado negativo para a detecção do LMV em plântulas obtidas em substrato pode ser atribuído a uma baixa concentração do vírus nas sementes no período de desenvolvimento da plântula em substrato. Wang et al. (1993) verificaram o desenvolvimento de plântulas sadias a partir de embriões infectados, o que pode ser devido à baixa concentração ou à localização do vírus nas sementes. A localização do LMV em sementes e plântulas de alface foi observada por Hunter e Bowyer (1993) pela presença de virions e inclusões citoplasmáticas em tecidos embrionários, indicando a replicação viral. A infecção viral no tecido apical durante a germinação é um indício de que a taxa de divisão celular excede o movimento do vírus para a plântula. De acordo com Wang et al. (1993), a invasão de embriões nem sempre é suficiente para induzir à transmissão do vírus das sementes para as plântulas.

Nos genótipos 'Vanessa Roxa', Baba de Verão', 'Verdinha' e 'Maravilha das 4 Estações', sem genes de resistência, houve transmissão do LMV das sementes para as plântulas, obtidas em papel filtro e não houve transmissão para as plântulas obtidas em substrato comercial (Tabela 1). O que pode ser atribuído ao genótipo ou a baixa concentração do vírus nas plântulas. A transmissão de vírus por sementes para plantas raramente atinge $100 \%$, porém em muitas cultivares a transmissão pode ser nula, devido à taxa de transmissão estar mascarada pela inviabilidade das sementes infectadas
(Nayudu, 2008). No presente trabalho houve transmissão do LMV das sementes para as plântulas obtidas em substrato nos genótipos 687, 784 e 'Marcela, que apresentavam genes de resistência sendo que no genótipo 784 houve, também, detecção do vírus nas plântulas obtidas em papel filtro (Tabela 2). Frequentemente, a transmissão do vírus de sementes para plantas ocorre pela infecção dos gametas antes da fertilização, mas a infecção do embrião também pode ocorrer após a fertilização, pela passagem do vírus para o núcleo ou para o embrião da planta-mãe (Nayudu, 2008).

$\mathrm{Na}$ avaliação individual das sementes, por PTA-ELISA, dos genótipos do BAG-IAC e BAG-EEH, agrupadas em lotes de 90 sementes, o LMV foi detectado em $100 \%$ das sementes dos genótipos sem gene de resistência 'Vanessa Roxa', 'Babá de Verão' e em $87,7 \%$ e 46,6\% para 'Verdinha' e 'Maravilha das 4 Estações', respectivamente. Nos genótipos com gene de resistência o LMV foi detectado em 90\%, 26,6\% e 15,5\% das sementes dos genótipos 784, 687 e 'Marcela', respectivamente (Tabela 3). As taxas de sementes infectadas podem indicar que as plantas mães dos genótipos 'Marcela', 687 e 784 tenham sido infectadas no campo pelo LMV-Most, uma vez que estes genótipos tiveram uma porcentagem de sementes infectadas superior a 1,33\% como ocorre com os genótipos infectados pelo LMV-Common (Jadão et al. 2002). Nos genótipos sem gene de resistência o LMV foi detectado nas sementes, com porcentagens que variaram de $16,6 \%$ a $100 \%$ (Tabela 3) resultado semelhante ao obtido por Jadão et al. (2002), no qual a porcentagem de sementes infectadas pelo LMV-Most de genótipos sem gene de resistência é de16,6\%.

Os valores médios da leitura da absorbância foram diretamente proporcionais ao número de sementes positivas em PTA-ELISA. Não houve diferenças entre o valor obtido pela divisão das médias das sementes infectadas sobre a média do controle negativo, com relação à porcentagem de sementes positivas em PTA-ELISA, entre os genótipos com e sem gene de resistência (Tabela 3 ).

Pelos resultados obtidos verificou-se que a detecção do LMV por PTA-ELISA foi mais eficiente em sementes do que em plântulas de alface, uma vez que houve detecção nas sementes de sete dos oito genótipos avaliados e somente em seis genótipos das plântulas, obtidas em papel filtro e substrato comercial (Tabelas 1,2).

De acordo com as recomendações da "International Seed Testing Association - ISTA" e "International Seed Federation - IFS" em análises de sanidade de sementes e plântulas de alface, recomenda-se empregar o método sorológico, para a detecção do LMV, utilizando-se para tanto uma amostragem mínima de 10.000 sementes divididas em 
subamostras de 500 sementes e de 2.000 plântulas divididas em subamostras de 100 plântulas. Na análise de sementes pode ser detectada 1 em 500 e na análise de plântulas pode ser detectada 1 em 100 (ISF, 2011).

Pelos resultados obtidos em PTA-ELISA demonstrouse a eficiência da técnica para a detecção do LMV em sementes e plântulas pela utilização de 1000 sementes de alface divididas em 10 subamostras de 100 sementes, que foi suficiente para a detecção segura do LMV. O que pode agilizar a interceptação do LMV em sementes comercializadas, por ser um processo rápido e com constante padrão de leitura de absorbância $\left(\mathrm{A}_{405}\right)$, das subamostras dos genótipos avaliados. Pela detecção do LMV em sementes individualizadas, foi estimada a porcentagem de sementes infectadas em cada genótipo avaliado. Foi constatada a eficiência do PTAELISA e a viabilidade de redução do número de sementes para a detecção do LMV, fator importante para a redução do número de sementes para análise, principalmente devido ao elevado custo de produção de sementes certificadas desta espécie de olerícola.

Tabela 3. Detecção do LMV por PTA-ELISA em sementes individualizadas pertencentes aos genótipos do Banco Ativo de Germoplasma.

\begin{tabular}{|c|c|c|c|c|c|c|c|}
\hline BAG & Genótipos & $\begin{array}{l}\mathrm{N}^{\circ} \text { sementes } \\
\text { (Avaliadas / } \\
\text { Infectadas) }\end{array}$ & $\begin{array}{c}\text { Sementes } \\
\text { infectadas } \\
(\%)\end{array}$ & $\begin{array}{c}(\mathrm{M})^{1} \\
\text { absorbância }\end{array}$ & $(\mathrm{MC}-)^{2}$ & $(\mathrm{M}) /(\mathrm{MC}-)^{3}$ & $(\mathrm{MC}+)^{4}$ \\
\hline \multirow{4}{*}{$\begin{array}{l}\text { BAG } \\
\text { (IAC) }\end{array}$} & 'Vanessa Roxa' & $90 / 90$ & 100 & 0,329 & 0,033 & 9,96 & 0,689 \\
\hline & 'Baba de Verão' & $90 / 90$ & 100 & 0,117 & 0,012 & 9,75 & 0,547 \\
\hline & 'Verdinha' & $90 / 79$ & 87,7 & 0,092 & 0,017 & 5,41 & 0,485 \\
\hline & $\begin{array}{c}\text { 'Maravilha } 4 \\
\text { Estações' }\end{array}$ & $90 / 42$ & 46,6 & 0,324 & 0,088 & 3,68 & 0,736 \\
\hline \multirow{4}{*}{$\begin{array}{l}\text { BAG } \\
(\mathrm{EEH})\end{array}$} & 687('Vera Sapore') & $90 / 24$ & 26,60 & 0,487 & 0,038 & 12,8 & 1,500 \\
\hline & 784 ('Vera Sapore') & $90 / 81$ & 90,00 & 0,133 & 0,013 & 10,23 & 0,771 \\
\hline & 'Marcela' & $90 / 14$ & 15,50 & 0,259 & 0,071 & 3,64 & 0,945 \\
\hline & 'Evely' & $90 / 15$ & 16,60 & 0,161 & 0,05 & 3,22 & 0,801 \\
\hline
\end{tabular}

1(M): Média da leitura da absorbância a $405 \mathrm{~nm}$ da amostra de sementes.

2(MC-): Média da leitura da absorbância a $405 \mathrm{~nm}$ do controle negativo.

${ }_{3}^{3}(\mathrm{M}) /(\mathrm{MC}-)$ : Média da leitura da absorbância a $405 \mathrm{~nm}$ das sementes sobre a média da leitura do controle negativo.

${ }^{4}(\mathrm{MC}+)$ : Média da leitura de absorbância a $405 \mathrm{~nm}$ do controle positivo.

\section{Conclusões}

A detecção por PTA-ELISA do LMV em sementes e plântulas de alface, independentemente da presença ou ausência de genes de resistência nos genótipos de alface avaliados, é eficiente para a detecção do vírus em sementes e em plântulas, em diferentes estádios de desenvolvimento. Em alguns genótipos o LMV não é detectado em plântulas, provavelmente pelo fato da transmissão do vírus das sementes para as plântulas, iniciar-se pela infecção do tecido embrionário, no qual a velocidade da multiplicação celular pode exceder a do movimento do vírus, para as plântulas.

\section{Referências}

BATISTA, M.F.; MARINHO, V.L.A. Virus e viroides transmitidos por sementes. Brasília: EMBRAPA, 2002. 74p.
BENNETT, C.W. Seed transmission of plant viruses. Advances in Virus Research, v.14, p.221-261, 1969.

BRASIL. Ministério da Agricultura, Pecuária e Abastecimento. Regras para análise de sementes. Ministério da Agricultura, Pecuária e Abastecimento. Secretaria de Defesa Agropecuária. Brasília, DF: MAPA/ACS, 2009. 395p. http://www.agricultura.gov.br/arq_editor/file/laborat $\%$ c3\%b3rio/ sementes/regras\%20para\%20analise \%20de\%20sementes.pdf

CHAVES, A.L.R.; COLARICCIO, A.; EIRAS, M.; GALLETI, S.R. Sonchus asper e $S$. oleraceous como reservatórios naturais de vírus em cultivos de alface no cinturão verde de São Paulo. Arquivos do Instituto Biológico, v.74, n.2, p.101-107, 2007. htpp://www.biologico.sp.gov.br/ docs/arq/v74_2/chaves.pdf

CHUNG, M.R.; AZEVEDO FILHO, J.A.; COLARICCIO, A. Avaliação da reação de genótipos de alface (Lactuca sativa l.) ao Lettuce mosaic virus (LMV). Bragantia, v.66, n.1, p.61- 68, 2007. http://www.scielo.br/ scielo.php? script $=$ sci_abstract\&pid $=$ s000687052007000100008\&lng $=\mathrm{e}$ $\mathrm{n} \& \mathrm{nrm}=\mathrm{iso} \& \mathrm{tlng}=\mathrm{pt}$ 
CLARK, M.F.; ADAMS, A.N. Characteristics of the microplate method of enzyme-linked immunosorbent assay for the detection of plant viruses. Journal of General Virology, v.34, p.475-483, 1977. http://vir. sgmjournals.org/content/34/3/475.full.pdf

COSTA, C.L. Vetores de vírus de plantas - I. Insetos. In: LUZ, W.C. (Ed). Revisão Anual de Patologia de Plantas (RAPP). Passo Fundo, 1998. p.103-171.

DANIELS, J. Quando o vírus está na semente. Cultivar hortaliças e frutas, v.1, n.5, p.34-35, 1999.

DINANT, S.; LOT, E.H. Lettuce mosaic virus: a review. Plant Pathology, v.41, p.528-542, 1992.

FALK, B.W.; PURCIFUL, D.E. Development and application of an EnzymeLinked Immunosorbent Assay (ELISA) test to index lettuce seeds for mosaic virus in Florida. Plant Disease, v.67, p.413-416, 1983. http://www. apsnet.org/publications/plantdisease/backissues/documents/1983articles/ plantdisease67n04_413.pdf

FAUQUET, C.M.; MAYO, M.A.; MANILOFF, J.; DESSELBERGER, U.; BALL, L.A. Virus Taxonomy: VIII ICTV Virus taxonomy report. New York: Academic Press, 2005. 1257p.

HULL, R. Matthews Plant Virology. Great Britain: Academic Press, 2002. 1001p.

HUNTER, D.G.; BOWYER, J.W. Cytopathology of lettuce mosaic virus-infected lettuce seeds and seedlings. Journal of Phytopathology, v.137, p.61-72, 1993 .

HUNTER, D.G.; BOWYER, J.W. Cytopathology of mature ovaries from lettuce plants infected by Lettuce mosaic potyvirus. Journal of Phytopathology, v.140, n.1, p.11-18, 1994.

INTERNATINAL SEED FEDERATION - ISF. 2011. http//worldseedorg/ sihis. Acesso em: 30 mar. 2012.

JADÃO, A.S.; PAVAN, M.A.; SILVA, N.; ZERBINI, F.M. Seed transmission of Lettuce mosaic virus (LMV) pathotype II and IV in different lettuce genotypes. Summa Phytopathologica, n.28, v.1, p.58-61, 2002.
KRAUSE-SAKATE, R.; LE GALL, O.E.; FAKHFAKH, H.; PEYPELUT, M.; MARRAKCHI, M.; VARVERI, C.; PAVAN, M.A.; SOUCHE, S.; HERVÉ, L.; ZERBINI, F.M., CANDRESSE, T. Molecular and biological characterization of Lettuce mosaic virus (LMV) isolates reveals a distinct and widespread type of resistance-breaking isolates : LMV-Most. Phytopathology, v.92, n.5, p.563-571, 2002.

KRAUSE-SAKATE, R.; MELLO, R.N.; ZAMBOLIM, E.M.; PAVAN, M.A.; CARVALHO, M.G.; LE GALL, O.E.; ZERBINI, F.M. Molecular characterization of two brazilian isolates of Lettuce mosaic virus (LMV) with distinct biological properties. Fitopatologia Brasileira, v.26, n.3, p.153 -157, 2001. http://www.scielo.br/scielo.php?script=sci_arttext\&p id $=$ s0100-41582001000200006

MAULE, A.J.; WANG, D. Seed transmission of plant viruses: A lesson in biological complexity. Trends in Microbiology, v.4, p.153-158, 1996.

NAYUDU, M.V. Plant viruses. New Delhi: Tata McGwaw-Hill, 2008. $1128 \mathrm{p}$.

PAVAN, M.A.; KRAUSE-SAKATE, R.; KUROZAWA, C. Doenças da alface. In: HIROSHI K.; AMORIM, L.; REZENDE, J.A.M.; BERGAMIN FILHO, A.; CAMARGO, L.E.A. (Ed.). Manual de Fitopatologia: doenças das plantas cultivadas. Piracicaba: CERES, 2005. v.2, p.27-33.

ROHLOFF, I.; MARROU, J. Lettuce, Lettuce Mosaic Working Sheet. In: Ista Handbook on Seed Health Testing. Zurich, 1981. p.1-4. (ISTA, n.9).

SHEPHERD, R.J. Transmission of viruses through seed of Phaseolus vulgaris L. cultivar Beka. Acta Botanica Neerlandra, v.12, p.433-497, 1972.

TOMLINSON, J.A. Lettuce mosaic virus. In: Comnionwealth Agricultural Bureaux. Association of Applied Biologists. Descriptions of plant viruses, n.9, 1970.

WANG, D.; WOODS, R.D.; COCKBAIN, A.J.; MAULE, A.J.; BIDDLE, A.J. The susceptibility of pea cultivars to pea seed borne mosaic virus infection and virus seed transmission. Plant Pathology, v.42, p.42-47, 1993.

ZERBINI, F.M. Transmissão e controle de vírus em sementes. In: ZAMBOLIM, L. (Ed.). Sementes qualidade fitossanitária. Viçosa: UFVDFP, 2005. p.135-154. 